\title{
From System Expansion to System Contraction: Access to Higher Education in Poland
}

\author{
MAREK KWIEK
}

\begin{abstract}
Access to higher education in Poland is changing due to the demography of smaller cohorts of potential students. Following a demand-driven educational expansion after the collapse of communism in 1989, the higher education system is now contracting. Such expansion/contraction and growth/decline in European higher education has rarely been researched, and this article can thus provide a possible scenario for what might occur in other European postcommunist countries. On the basis of an analysis of microlevel data from the European Union Survey on Income and Living Conditions, I highlight the consequences of changing demographics for the dilemmas of public funding and admissions criteria in both public and private sectors.
\end{abstract}

\section{Introduction}

The article explores access to higher education in Poland in a specific moment in which demand-driven educational expansion after the collapse of communism in 1989 is declining due to demographic factors. The pairs of expansion/contraction and growth/decline in European higher education, related to demographic trends, have not been discussed in the research literature so far, and this article is intended as a contribution to the themes expected to be highly relevant in Central and Eastern Europe. The article shows that the processes of intersectoral public/private differentiation characterizing an expanding higher education sector may be gradually replaced with the processes of the intersectoral homogenization of the contraction era. Public policies and institutional strategies for that era have to be reinvented if the trend of inequality reduction in access to higher education is to be continued. The article combines a theoretical framework with substantial original data analysis. Its empirical evidence comes from both Polish national educational statistics and Polish national statistical demographic projections. Two sections in particular provide detailed analyses of original empirical data: the next section presents analyses of educational expansion in Poland in 1995-2010 based on four major dimensions: age, gender, sector (public/private), and status (full- and part-time). The "Inequality in Access to Higher Education" section is based on the microdata analysis of the EUSILC data set (European Union Survey on Income and Living Conditions)

I would like to express my gratitude to the three anonymous reviewers who provided their invaluable input in two rounds of revisions to the article. Their constructive criticism was enormously helpful for its improvement. All mistakes are solely my responsibility, though. I also gratefully acknowledge the support of the National Research Council (NCN) through grant DEC-2011/02/A/HS6/00183. 
and explores the relative mobility of the Polish society across generations (in terms of educational attainment levels and occupational groups) in a European comparative perspective. The article contributes to several lines of theory in global higher education research: global comparative research on private higher education (and, relatedly, public/private dynamics), research on intersectoral and intrasectoral differentiation of higher education, international comparative research in postcommunist European higher education systems, and international comparative research on social stratification.

Two aspects of the national context need to be emphasized from the outset. First, the Polish higher education system shows complicated intersectoral public/private dynamics and one of the highest degrees of marketization in Europe. In 2010, it had the highest share of enrollments and enrollment numbers in the private sector of all European countries, 31.5 percent $(0.56$ million), and a high share of fee-paying students, 51.6 percent (GUS 2011). Studies in the public sector are either tuition-free (full-time) or fee based (part-time), while studies in the private sector are fee based in both full-time and part-time modes. Second, there are radical demographic changes projected for the next 3 decades. The population of the 19-24 age group is projected to decrease between 2007 and 2025 by 43 percent (GUS 2009), and the number of students is projected to decrease from 1.82 million (in 2010) to 1.33 million (in 2020) to 1.17 million (in 2025; see VincentLancrin 2008; IBE 2011; Instytut Sokratesa 2011).' The decline in student numbers in the coming decade is a relatively disregarded parameter in national higher education strategies (see Ernst \& Young 2010), in international country reports by both the Organization for Economic Cooperation and Development (OECD) and the World Bank, as well as in academic discussions of mass higher education in Poland (Bialecki and Dąbrowa-Szefler 2009). The article links access to higher education in Poland to the exploration of different past roads of expansion of the system and to implications of the system contraction. After a discussion of system expansion, this article proceeds to analyze selectivity in Polish higher education in the past period of expansion and in the currently contracting system, in connection with possible changes in patterns of financing higher education. Then the article discusses patterns of access to higher education across Europe in order to provide context to the Polish case, from the perspective of intergenerational social mobility, as shown through the logistic regression analysis. Before concluding, the article discusses the links between demographic projections for Polish higher education and the future public/private dynamics, especially

\footnotetext{
${ }^{1}$ Recently, the Ministry of Science and Higher Education (2012) presented its own projections of the size and composition of higher education in the next decade: it expects 1.26 million students in 2022 ( 69 percent of the 2010 size) distributed among the public ( 88 percent) and private ( 12 percent) sectors. The private sector enrollment is thus expected to decrease almost five times, from 660,000 students in 2007 to 151,000 students in 2022.
} 
in the context of the possible introduction of universal fees in the public sector.

\section{System Expansion and Its Major Parameters}

It is generally assumed in scholarly and policy literature that major higher education systems in the European Union (EU) and in the OECD area will continue to expand in the next decade (King 2004; OECD 2008; Santiago et al. 2008; Altbach et al. 2010; Attewell and Newman 2010; EC 2011). Expanding systems generally contribute to social inclusion almost by definition because, as recently emphasized in a large-scale comparative study on stratification in higher education, the expanding pie "extends a valued good to a broader spectrum of the population" (Arum et al. 2007, 29). In the knowledge economy, expansion of higher education systems is key, and higher enrollment rates and increasing student numbers in the EU have been viewed as a major policy goal leading to economic growth by the European Commission throughout the last decade (EC 2011; Kwiek and Kurkiewicz 2012). In Poland, until recently, questions of admission, selection criteria, and funding mechanisms were raised under the assumption of an expanding system, with ever-growing numbers of both students and institutions (Duczmal and Jongbloed 2007; Bialecki and Dąbrowa-Szefler 2009; Dobbins 2011). Those questions may need to be reformulated for the coming decades of system contraction, however. Dramatically changing demographics introduce new dilemmas involving public funding and admission criteria. The article is highly relevant to other Central and Eastern European countries with similar admission patterns (with public/private dynamics) and similar future demographic trends (e.g., Bulgaria, Romania, Estonia, Lithuania, Latvia, and Slovakia, as well as, to a smaller degree, the Czech Republic, Hungary, and Slovenia). Research on the 2 decades of expansion here is combined with a brief exploration of possible implications of the contraction of the higher education system as far as access is concerned.

Access to higher education, credentials from it, and employability are closely linked (Knight 2009; Schomburg and Teichler 2011). In general, throughout 1990-2010 in Poland, there was a clear divide between credentials from traditional metropolitan, elite public universities (in tuition-free, fulltime mode of studies) and credentials from all other types of institutions and modes of studies (a part-time fee-paying mode of studies in the Polish context being much less academically demanding than a tuition-free fulltime mode). The hierarchy of institutions and programs was clear: "most highly valued were non-paying regular courses in trendy and attractive fields of study at several renowned state universities" (Bialecki and Dạbrowa-Szefler $2009,194-95)$. Selection criteria are demanding in the former case only. Consequently, educational outcomes, the quality of diplomas, and life chances of 
graduates in the labor market tend to differ increasingly, leading to the diversification and segmentation of the Polish higher education system.

Generally, strict meritocratic criteria are used for admissions only in two cases: in highly competitive elite metropolitan universities and in less competitive nonelite regional public universities-but only in their tax-based or tuition-free modes of study. In all other cases, higher education for the last 2 decades has been open to all those who could afford it and who met the basic formal criterion: the possession of a secondary school matriculation certificate. Higher education in all other cases became affordable because of the "quasi-market" competition (Le Grand and Bartlett 1993) among the ever-growing number of private higher education institutions (328 in 2011) and all public institutions (132 in 2011) that were then increasingly involved in providing additional part-time, fee-based studies. The large-scale competition for fee-paying students led to open access policies for them in both sectors (Kwiek 2008, 2010).

In the first decade of expansion (in the 1990s) after the collapse of communist rule, the difference between graduating from elite metropolitan public universities and graduating from all other types of institutions was not an issue of public concern. The differences in the life chances of graduates were not clearly visible. Families with high socioeconomic capital, usually from the former class of intelligentsia then turning gradually into the new middle class of professionals, were sending their children to the full-time, tuition-free courses in elite metropolitan public universities, as they always did in the whole postwar period. Social structure in Poland shows not only substantial inheritance of education and occupations across generations, as discussed in more detail below, but also very substantial inheritance as far as institutional types of higher education are concerned: first-generation students are far more likely to choose academically less demanding higher education, that is, the fee-based, part-time mode of study, in both sectors.

The expansion took different routes, as we shall see; to a large extent, these routes determine the routes of future contraction and major policy strategies to combat it. The expansion is disaggregated here into four components: expansion by age, by gender, by sector (public/private), and by student status (full-time/part-time). Overall, student numbers increased from about 790,000 to about 1,841,000 (or by 133 percent). Ireneusz Bialecki and Małgorzata Dabrowa-Szefler $(2009,185)$ have recently described the drivers to the expansion in enrollments as follows: "on the one hand, the society's growing educational aspirations and, on the other, a significant broadening of the tertiary-level education on offer."

Analyzing the age structure of students in 1995 and in 2010, the increase in enrollments was most marked in the traditional student age group (70 percent of that increase concerned those aged 19-24, and 30 percent those aged 25 and higher). While the enrollment increase in the former age group 
ACCESS TO HIGHER EDUCATION IN POLAND

TABLE 1

COMPOSITION OF ENROLLMENT INCREASE, 1995-2010

\begin{tabular}{|c|c|c|c|c|c|}
\hline & 1995 & 2010 & 1995-2010 & $\%$ Change & $\begin{array}{l}\text { \% Distribution } \\
\text { of Increase }\end{array}$ \\
\hline Full-time & 449,805 & 949,476 & 499,671 & 111.09 & 47.51 \\
\hline Part-time & 339,635 & 891,775 & 552,140 & 162.57 & 52.49 \\
\hline Total & 789,440 & $1,841,251$ & $1,051,811$ & 133.24 & 100.00 \\
\hline Men & 346,485 & 758,768 & 412,283 & 118.99 & 39.20 \\
\hline Women & 442,955 & $1,082,483$ & 639,528 & 144.38 & 60.80 \\
\hline Total & 789,440 & $1,841,251$ & $1,051,811$ & 133.24 & 100.00 \\
\hline Public & 700,514 & $1,261,175$ & 560,661 & 80.04 & 53.30 \\
\hline Private & 88,926 & 580,076 & 491,150 & 552.31 & 46.70 \\
\hline Total & 789,440 & $1,841,251$ & $1,051,811$ & 133.24 & 100.00 \\
\hline
\end{tabular}

SOURCE.-Own calculations based on GUS $(1996,2,192-93 ; 2011,55,138-42)$.

was about 955,000 , in the latter it was about 405,000 (GUS 1996, 2011). The expansion was also heavily gendered: about 40 percent of the increase involved male students, and about 60 percent involved female students. Consequently, the feminization of studies, already present in 1995, became even more pronounced in 2010: while the increase in the number of male students during that period was about 412,000 , for female students it was about 640,000 , that is, more than 50 percent higher (GUS 1996, 2011). From a public/private sectoral perspective, despite the emergence and massive growth of the private sector during that time, the private sector accounted for slightly less than half of the total growth (about 47 percent, or about half a million students; GUS 1996, 2011). Finally, the expansion was fueled slightly more by fee-based, part-time studies in both sectors than by full-timers. The number of part-timers increased from about 340,000 in 1995 to about 890,000 in 2010 . As a consequence of the 163 percent increase in the number of part-timers, the distribution of the 1995-2010 increase was about 48 percent for full-time students and about 52 percent for part-time students (GUS 1996, 2011). To sum up, the distribution of the expansion in the period studied was as follows: new students were mostly of a traditional age (70 percent), female ( 60 percent), and studying slightly more often in a part-time mode (52 percent) and slightly more often in the public (53 percent) than in the private sector (see table 1 for a summary of the composition of the enrollment increase in 1995-2010.

The past distribution of increase in enrollments (by age, gender, sector, and status) in the period of educational expansion is highly relevant for the possible distribution of the decrease in enrollments in the contraction period and for national policies to combat it. Patterns of expansion may even determine policy choices in combating contraction. For instance, one obvious way to combat contraction in light of the analyses above is to increase the participation rate of both male and female older students and of male students in the usual 19-24 age bracket. Other traditional tools for increasing 
student numbers, known from other systems, may well fail; these normally include lowering the proportion of early school-leavers, increasing the transition rate from secondary to higher education, increasing the graduation rate from higher education, and increasing enrollment rates (including from different age cohorts). But as a recent report shows, Poland already has the second lowest rate- 5 percent-for early school-leavers in the EU (after Slovenia; EC 2009); Poland also ranks first in entry rates at the higher education level, with 85 percent in 2009 (OECD 2011), and second in graduation rates at the higher level (after Slovakia, with 50.2 percent; OECD 2011). Finally, enrollment rates are already higher than the average for both $\mathrm{EU}$ and $\mathrm{OECD}$ countries, having reached 53.8 percent in 2010 (GUS 2011). Consequently, compared with other European systems, traditional tools of increasing enrollments, apart from bringing older students to higher education, seem ineffective.

As discussed above, the expansion was accompanied by a slow and gradual hierarchical differentiation of the system (see Goedegebuure et al. 1996; Meek et al. 1996b; Huisman and van Vught 2009). Much of the growth was absorbed by public and private second-tier institutions and by first-tier public institutions in their academically less demanding and less selective part-time studies. The expansion also took place in specific fields of study, in particular, the social sciences, economics, and law. In 2000, the share of enrollments in these fields was 37 percent in the public sector and 72 percent in the private sector, and a decade later it was still 32.8 and 52.6 percent, respectively (GUS 2011). When, as in the Polish case, quantitative equality is reached in higher education, qualitative differentiation becomes increasingly important: "qualitative differentiation enables education systems to reduce inequalities along the quantitative dimension because qualitative differences replace quantitative ones as the basis for educational selection" (Shavit et al. 2007, 44). Qualitative differentiation means different types of institutions and different types of study programs.

While communist-period higher education in 1970-90 in Poland could be termed unified (following both Meek et al. [1996a] and Shavit et al. [2007]), the last 2 decades of its expansion show a transformation from a unified to a diversified system. Unified systems "are controlled by professional elites who are not inclined to encourage expansion, either of their own universities or through the formation of new ones" (Shavit et al. 2007, 5). Higher education in Poland was also predominantly "a political force and a political institution . . given precise political tasks” (Szczepański 1974, 7). The number of students in the 2 decades of 1970-90 was strictly controlled and fluctuated between 300,000 and 470,000. The strict numerus clausus policy was the rule in all Central European countries: admissions were part of central planning and closely controlled by the state. In Poland, in 1951-60 about 89 percent of those age 19 went on to higher education; in 1961-70 it was 
between 10 and 13 percent, in 1971-80 between 12 and 16 percent, and in 1981-89 between 11 and 13 percent. The numerus clausus policy placed restrictions on the total number of students and enrollments in particular study fields. While Western European systems were already experiencing massification in the 1970 s and 1980s, higher education in Central Europe was as elitist in 1989 as in decades past. After the 1989 collapse of communism, one of the major reasons for the phenomenal growth of private higher education in (some) Central European countries, and particularly in Poland, was newly opened private-sector employment. Increasing salaries in the emergent private sector gradually pushed young people into higher education. Consistent with Roger Geiger's findings, the private sector in Poland was forced to operate "around the periphery of the state system of higher education" (1986, 107).

\section{System Expansion and Selectivity in Higher Education}

Newcomers to the education sector after 1989, especially from lower socioeconomic classes, were going in droves to new regional public universities and to fee-based tracks in elite metropolitan public universities, as well as to the emergent fee-based establishments of the private sector. In the first decade of expansion, the difference between graduating from various types of institutions seemed largely irrelevant, especially to first-generation students and their families. After 1989, "the 'entrepreneurial spirit' and 'possessive individualism'-which had been blocked under communism by administrative obstacles-found an outlet" (Domański 2000, 29). Higher education credentials from any academic field, any institutional type, and any mode of study were viewed as a ticket to good lives and rewarding jobs by the newcomers.

The most valuable vacancies-those in elite metropolitan public universities in full-time mode of study-were scarce, and access to them was competitive. They were socially valuable not only because they were tuition-free but because they were academically demanding (Bialecki and Dąbrowa-Szefler 2009). All other vacancies, which were much less socially valuable from a broader perspective and perceived as such by the intelligentsia-turnedmiddle classes, were offered to all, in fee-based modes, throughout the last 2 decades (1990-2010). During the expansion period, higher education was both accessible and affordable (Duczmal and Jongbloed 2007), and the recognition of its differentiation by type of institution and by mode of studies was low. Paradoxically, the lack of clear differentiation of the educational arena may have seemed in the interest of all stakeholders: students and their parents, public and private institutions, and the state. The state boasted everrising enrollment rates and increasing education of the workforce; public institutions offered part-time studies for fees, and this noncore nonstate income played a powerful role in maintaining the morale of academics through 
increasing their university incomes; and private institutions were showing all elements of a traditional institutional drift - they were emulating public institutions. The gradual stratification of the system was increasingly being taken for granted and governed most student choices only in the second decade of the expansion, when the labor market was saturated with new graduates (totaling about 2 million in 1990-2003).

During the time of expansion, questions about equitable access and fair selection criteria were not raised, and issues of social justice emerged neither in official policy documents (including several national strategies for higher education and official rationales for new draft laws on higher education; see Ernst \& Young 2010) nor in scholarly publications. Expansion was viewed as a public good in itself, and issues related to fairness and inclusion were generally underresearched in academia and underdebated in the public sphere. Official higher education statistics and labor force statistics showed a highly positive picture of an emergent well-educated society with an increasing share of the workforce with higher education credentials. National and regional statistics did not differentiate among types of institutions attended and modes of study selected. But the system expansion stopped around 2005, and enrollments contracted from about 2 million to about 1.76 million in 2011. The contraction is expected to continue at least until 2025.

The expansion in Poland in both the public and the private sectors was demand driven: students and their families wanted more access to higher education after the collapse of communism, and their demand was increasingly being met (Duczmal and Jongbloed 2007; Kwiek 2008, 2009; Bialecki and Dąbrowa-Szefler 2009). Higher education was no longer strictly rationed by the state, and massification was fueled by both sectors and modes of study. External shocks related to the "postcommunist transition" in the economy and the financial austerity in the academy prevalent throughout the $1990 \mathrm{~s}$ were driving the dynamics of institutional change. Universities were driven by expansion-related phenomena, and they responded in the way a "resource dependence" perspective used in organizational studies would expect-by seeking to survive, in the mutual processes of interaction between organizations and their environments (Pfeffer and Salancik 1978; see also van Vught 2009) at both the microlevel of individuals and the mesolevel of institutions. ${ }^{2}$

The Polish system is more market based than most state-funded European systems but also much more state funded than most global market-based systems, including in the United States, Korea, or Japan (Kwiek 2006, 2013). The increasing differentiation of higher education institutions along the "client-seeking" and "prestige-seeking" lines is what happens when the system expands. As Richard Arum et al. $(2007,8)$ emphasize, "client-seeking implies low admissions criteria while status-seeking implies fewer clients than could

${ }^{2}$ On the consequences of the fee-based revenues for the university research mission, see Kwiek (2012a) and Kwiek and Maassen (2012). 
otherwise be admitted. The conflict is often resolved through the differentiation of a status-seeking first tier of institutions and a client-seeking second tier, which is less selective and enjoys lower prestige." What will happen to the process of differentiation in times of system contraction? All institutions, public and private, might be forced to become increasingly client seeking (with perhaps no significant difference in whether the clients will be tuitionfree students funded by the state or self-funded, fee-based students and regardless of whether universal fees in the public sector are finally introduced in the coming decade). The public sector may find it necessary to become aggressively client seeking, as the private sector was throughout the last 2 decades. In contracting systems, the selectivity of institutions in both sectors will decrease over time. Admissions criteria will become less stringent, and access for candidates from lower socioeconomic classes may be less and less based on meritocratic criteria in public institutions that today are highly selective. All institutions, public and private alike, will try to maintain their current capacities, infrastructures, and academic workforce.

Consistent with findings in the global private higher education literature, the largest growth in Polish private higher education occurred through the nonelite, mostly demand-absorbing, types of institutions (Geiger 1986; Levy 2009,2011 ). As elsewhere in rapidly expanding systems, most students were "not choosing their institutions over other institutions as much as choosing them over nothing" (Levy 2009, 18). As in other countries, the demandabsorbing private subsector tended to be both the largest private subsector and the fastest growing one. Now this is the most vulnerable subsector, as the number of students goes down. The growth of private higher education did not necessarily mean "better" services or "different" services; rather, it meant most of all "more" higher education (Geiger 1986; Enders and Jongbloed 2007). Consistent with Geiger's (1986) findings about "peripheral private sectors" in higher education, as opposed to "parallel public and private sectors," the university component of higher education was monopolized by public institutions, and the nonuniversity, postsecondary component by private institutions. "Market segmentation" rather than open competition with the huge, dominant public sector obtained, and the most salient feature of the private sector institutions throughout the last 2 decades remained the fact that they operated as "special niches" (Geiger 1986, 158).

Recent policy proposals about the public subsidization of the private sector and about the introduction of universal fees in the public sector seem to indicate a possible change in policy patterns in financing higher education. Following Daniel C. Levy's typology of public/private mixes in higher education systems (1986), recent policy proposals might indicate a policy move toward the homogenization of the two sectors. Indeed, public/private blends raise a number of important questions: Will there be a single sector or a dual one? If there is a single sector, will it be statist or public autonomous? If there 
is a dual sector, will it be "homogenized" or "distinctive"? If it is "distinctive," will it be minority private or majority private? Within this typology, the move would be from the fourth pattern to the third one. That is, a dual, distinctive higher education sector (a smaller private sector funded privately and a larger public sector funded publicly) would become a dual, homogenized higher education sector (with a minority private sector and similar funding for each sector; Levy's first and second patterns refer to single systems, with no private sectors). The policy debates about public/private financing emergent in Poland today are not historically or geographically unique. Levy identified three major policy debates in his fourth pattern of financing: the first concerns the growth of private institutions, the second concerns whether new private sectors should receive public funds, and the third concerns tuition in the public sector. While in the expansion period of the 1990s the debate about the growth of the private sector was the dominant one in Poland, in all likelihood the contraction period of the 2010 s will see a shift toward controversies over fees and public subsidies.

Still, the question of inequality in access to higher education, while usually raised in the context of educational expansion, could also be raised in the context of educational contraction. The contraction expected in Poland is at odds with the dominant knowledge-economy policy discourse that emphasizes the ever-increasing need for a better educated workforce (see, e.g., Santiago et al. [2008], EC [2011], and education attainment benchmarks in the EU Europe 2020 strategy for growth and jobs) and an increase in the number of students. This European policy discourse largely ignores sharply falling demographics and expected decreases in enrollments in major postcommunist European countries, with Poland in the forefront.

\section{Inequality in Access to Higher Education: A Note on Poland in a European Comparative Perspective}

A decade and a half of continuous educational expansion in Poland could be expected to have reduced social inequality in access to higher education and to have enabled faster upward social mobility thereby. Traditionally, higher education is the main channel of upward social intergenerational mobility (see DeShano da Silva et al. 2007; Holsinger and Jacob 2008). Intergenerational social mobility reflects equality of opportunity; class origins in less mobile societies determine educational trajectories and labor market trajectories to a higher degree than in more mobile societies (Archer et al. 2003; Bowles et al. 2005; Furlong and Cartmel 2009). Younger generations "inherit" education and "inherit" occupations from their parents to a higher degree in less mobile societies.

My brief comparative analysis of social mobility is intended as a note on the broader social context of expansion and contraction processes in higher 
education. It is based on microdata from the EU-SILC. ${ }^{3}$ For research on intergenerational educational and occupational mobility in Poland, the EUSILC 2005 module "The Intergenerational Transmission of Poverty" is most useful. The module provides data for attributes of respondents' parents during their childhood (age 14-16) and reports the educational attainment level and the occupational status of each respondent's father and mother. In almost all European OECD countries, there is "a statistically significant probability premium of achieving tertiary education associated with coming from a higher-educated family, while there is a probability penalty associated with growing up in a lower-educated family" (Causa and Johansson 2009b, 18). Fairness in access to higher education in Poland is linked to the issue of intergenerational transmission of educational attainment levels and occupational statuses of parents considered from a European comparative perspective. If Polish society is less mobile than other European societies, then the need for more equitable access to higher education is greater.

I conduct a brief assessment of the relative risk ratio of inheriting levels of educational attainment and occupations in transitions from one generation to another generation in Poland, compared with other European countries. Relative risk ratios show how many times the occurrence of a success is more probable for an individual with a given attribute than for one without it. In this case, "success" is the respondent's higher education, and the attribute is his or her parents' higher education. Relative risk ratios show how an attribute of one's parents makes it more likely that the respondent (offspring) will share the same attribute (see Causa and Johansson 2009a, 2009b). Similarly, in OECD analyses, the risk ratio of achieving tertiary education is defined as "the ratio of two conditional probabilities. It measures the ratio between the probability of an offspring to achieve tertiary education given that her/his father had achieved tertiary education and the probability of an offspring to achieve tertiary education given that her/his father had achieved below-upper secondary education. Father's educational achievement is a proxy for parental background or wages" (Causa and Johansson 2009b, 51). Relative risk ratios were estimated using logistic regression analysis for the weighted data. A binomial model was used. Multinomial dependent variables were dichotomized, and separate models were constructed. The choice of independent variables was made using a back-step method and Wald criterion.

Among European countries, Poland has one of the highest relative risk ratios (10.6) for persons with higher education to have parents who had a higher education experience themselves. To be more specific, it is highly unlikely for children to have a higher education if their parents did not also

\footnotetext{
${ }^{3}$ The EU-SILC collects microdata on income, poverty, and social exclusion at the level of households and collects information about individuals' labor market statuses and health. The database includes both cross-sectional data and longitudinal data. For most countries of the pool of 26, the most recent data available are of 2007 and 2008.
} 
achieve the same level of education. In Poland, for a person whose parents had attended an institution of higher education, the probability of attaining higher education is 10.6 times higher than for a person whose parents did not. There are only four European systems that markedly stand out in variation (Poland, Portugal, Italy, and Ireland-plus the two small systems of Luxemburg and Cyprus). In all of them, having parents who attained higher education makes one's own probability of attaining higher education 10 times higher than it would otherwise be. While higher education is being "inherited" all over Europe, in Poland this ratio is on average almost two times higher than in other European countries (the average for 26 countries is 6.06 , and the average for eight postcommunist countries is 5.97). The details are given in figure $1 .{ }^{4}$ On the basis of the EU-SILC data, one can follow the transmission of education and the transmission of occupations across generations and see that parental educational and occupational backgrounds are reflected in those of their offspring. Educational status and occupational status are self-perpetuating attributes carried across generations (Archer et al. 2003; Breen 2004).

Figure 2 shows the probability of respondents achieving higher education given that their parents had achieved a primary level of education. The more mobile the society, the higher that probability will be. There is a major divide between a cluster of countries in which there is a low probability of upward mobility-in the range of 4-6 percent-and a cluster of countries in which the probability of upward mobility is three to four times higher, in the range of 17-23 percent. The low-probability cluster includes Poland and several other former communist countries, as well as Italy, and the high-probability cluster includes the Nordic countries, Belgium, Germany, Estonia, Spain, and the United Kingdom. The probability of upward intergenerational mobility through higher education, from a comparative perspective, is obviously very low in Poland. The percentage of people with higher education whose parents attended only primary school is 6 percent.

One can also look at the rigidity of educational backgrounds-that is, the transmission of the same level of education (primary to primary, higher to higher) across generations. What is particularly relevant here is the inheritance of higher education. Figure 3 shows that in all 26 European countries studied (except Slovenia), the chance of attaining higher education if one's parents have also attained higher education is more than 50 percent. The lowest range (50-60 percent) is found in several postcommunist countries, as well as in Denmark, Austria, Norway, Germany, and Sweden. The highest range (70-79 percent) obtains only for Spain, Ireland, and Belgium, as well as Luxembourg and Cyprus. Poland (67 percent) is in the upper-

\footnotetext{
${ }^{4}$ In fig. 1 , the cross-country results are presented for the $35-44$-year-old cohort. The module is based on data from personal interviews only. Variables analyzed were PM040 ("Highest ISCED level of education by father"), PM060 ("Main activity status of father"), and PM070 ("Main occupation of father").
} 


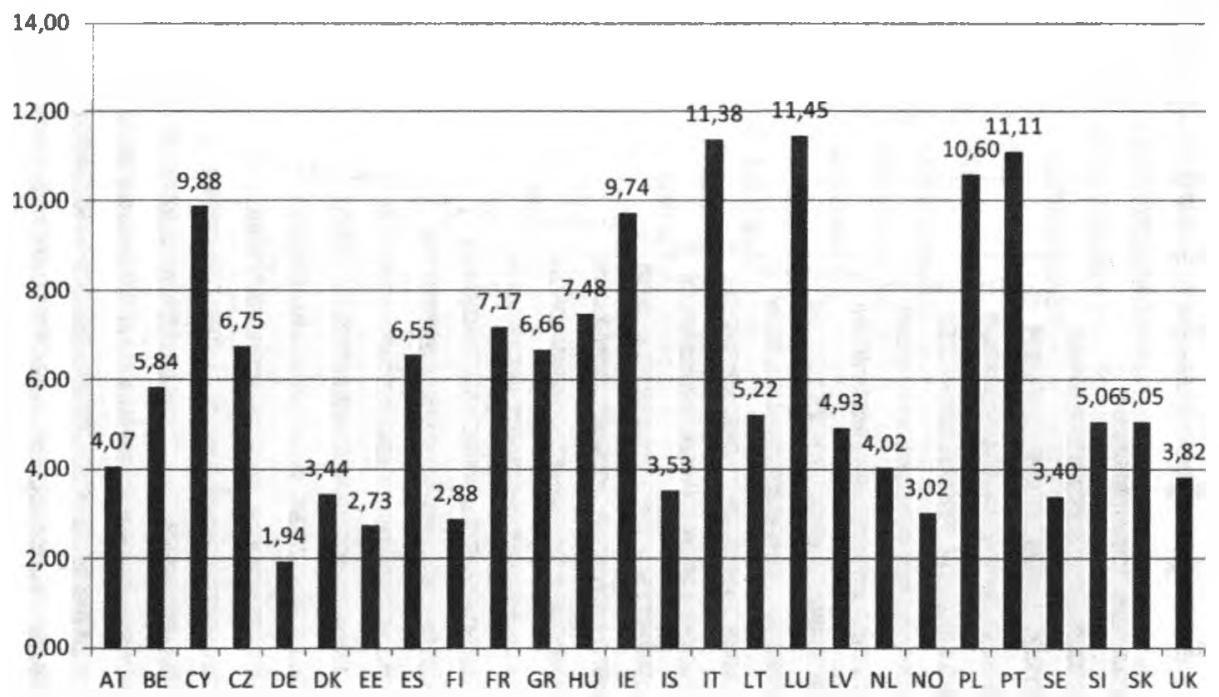

Fic. 1.--Relative risk ratio for persons with higher education in relation to their father's higher education. SouRCE. - Own study based on EU-SILC 2005 module "The Intergenerational Transmission of Poverty."

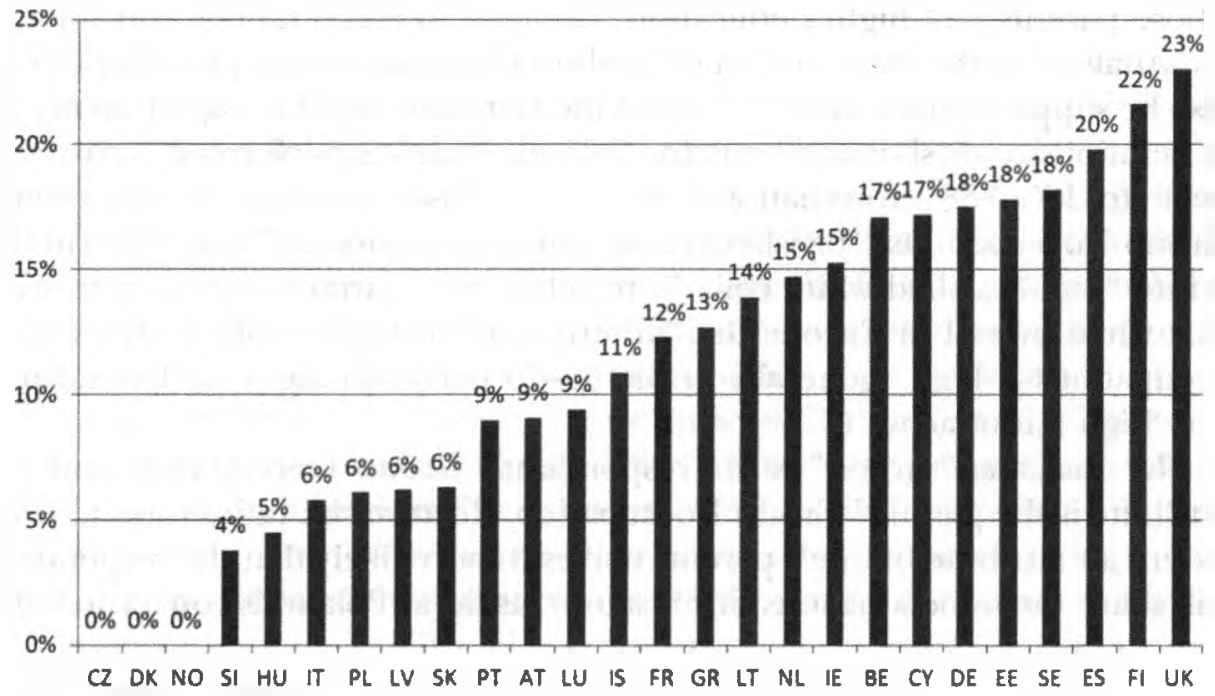

Fig. 2.-Transition from parents' primary education to respondent's higher education ( 0 percent for Czech Republic, Denmark, and Norway results from too few respondents in these countries). SOURCE. - Own study based on EU-SILC 2005 module "The Intergenerational Transmission of Poverty." 


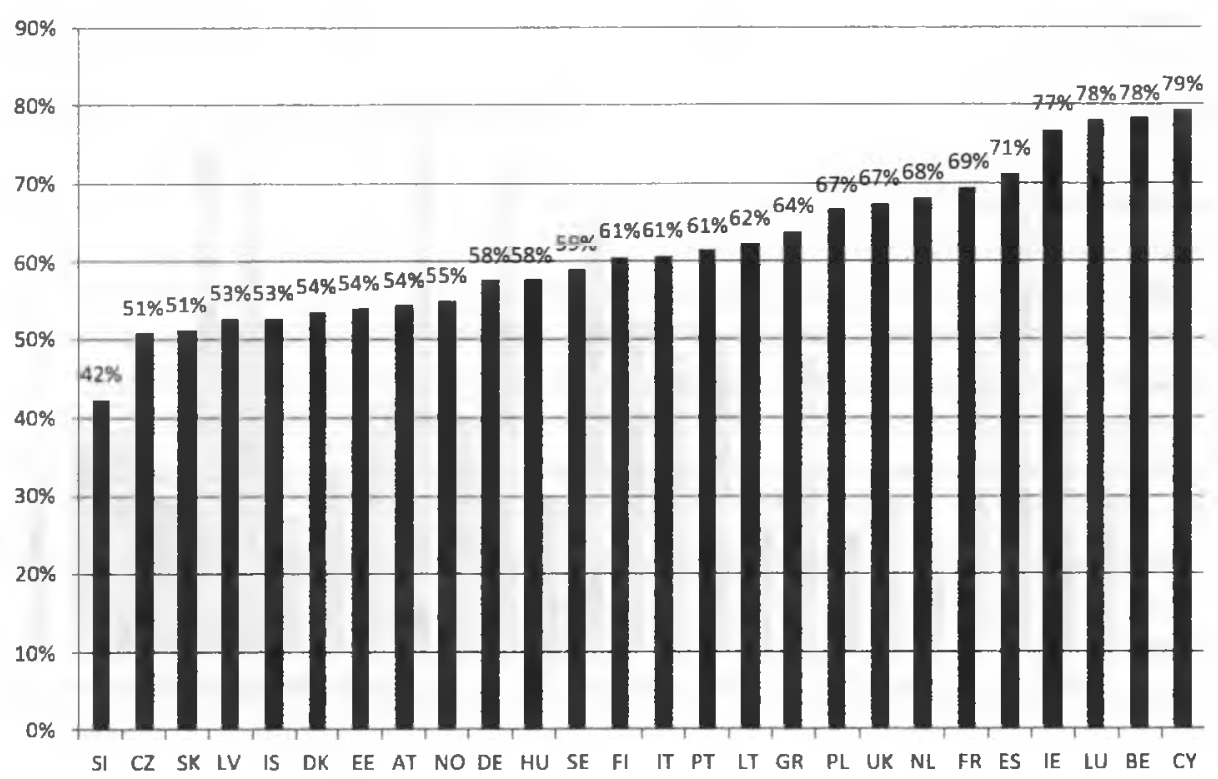

Fig. 3.-Transition from parents' higher education to respondent's higher education. SouRCE. Own study based on EU-SILC 2005 module "The Intergenerational Transmission of Poverty."

middle range of 65-70 percent and ninth from the top: 67 percent of people whose parents had higher education managed to attain higher education.

Analyses of the transmission of levels of education across generations can also be supplemented with analyses of the transmission of occupations across generations, with similar results for Poland. Analyses performed with reference to ISCO-88 (International Standard Classification of Occupations) Group 1 occupations ("legislators and senior professionals," translated in fig. 4 into "highly skilled white collar") in relation to parents' occupation show that while overall in Europe the "inheritance" of highly skilled white-collar occupations is high (generally in the 50-70 percent range), in Poland it is very high and reaches 67 percent. $^{5}$

In this case, "success" is the respondent's Group 1 occupation and the attribute is the parents' Group 1 occupation. Relative risk ratios show to what extent an attribute of one's parents makes it more likely that the respondent will share the same attribute. For instance, as far as Poland is concerned, the

\footnotetext{
${ }^{5}$ The analysis presented in fig. 4 aggregated the nine ISCO- 88 basic occupational groups, following the recent EUROSTUDENT IV study (Orr et al. 2011, 55), into the following four groups of workers: "highly-skilled white-collar" (1: legislators, senior professionals; 2: professionals; and 3: technicians and associate professionals), "low-skilled white-collar" (4: clerks; 5: service workers and shop and market sales workers), "highly skilled blue-collar" (6: skilled agriculture and fishery workers; 7: craft and related trades workers), and "low skilled blue-collar" (8: plant and machine operators and assemblers; 9: elementary occupations).
} 


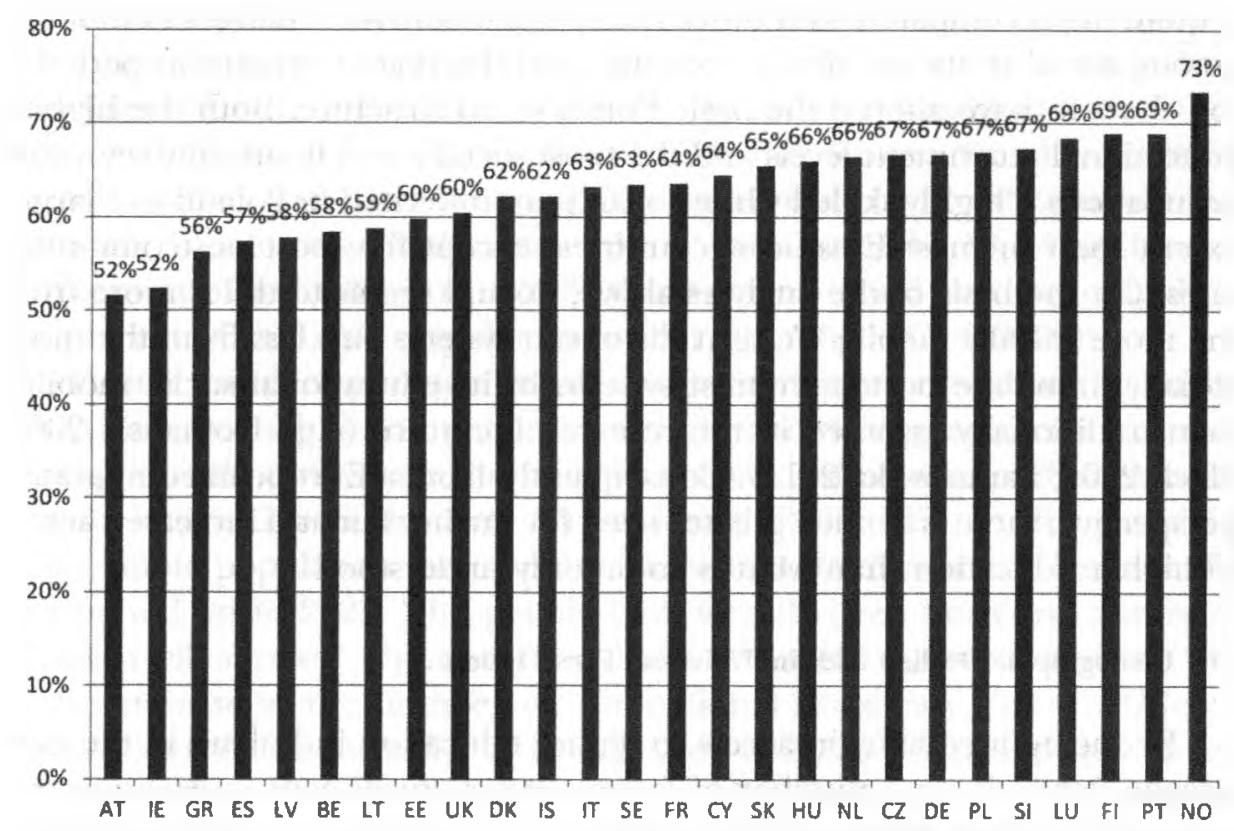

FIG. 4.-Transition from parents' highly skilled white-collar occupation to respondent's highly skilled white-collar occupation. SourcE.-- Own study based on EU-SILC 2005 module "The Intergenerational Transmission of Poverty."

probability that a person whose father was a legislator or senior professional will have an occupation of the same category is 3.32 times higher than for a person whose father had a different occupation; the probability that a person whose father had an "elementary" occupation will have a legislator or senior professional occupation is 1.49 times lower than for a person whose father had an occupation other than elementary. For Poland, the probability that a person whose father had an elementary occupation will have an occupation of the same category is 2.11 times higher than for a person whose father had a different occupation. Figure 4 shows that, in Poland, 67 percent of persons whose fathers had highly skilled white-collar occupations end up having the same occupation. The degree to which individuals "inherit" higher education and highly skilled white-collar occupations is therefore high, and successful transitions across generations from primary education to higher education and from low-skilled blue-collar occupations to highly skilled whitecollar occupations are rare.

Thus, to summarize the comparative findings: from a broad historical perspective, despite the 1990-2005 expansion in higher education, upward educational social mobility in Poland is still limited, and the level of inheritance of both educational status and occupational status across generations 
is quite high, compared with other European countries. Changes in mobility among social strata are slow in coming, and the recent expansion period is too short to have altered the basic Polish social structure. Both the highest educational attainment levels and the most socially and financially rewarded occupations ("highly skilled white-collar") are inherited in Poland to a larger extent than in most European countries, except for most postcommunist ones. On the basis of the analyses above, Poland seems to differ more from the more socially mobile Western European systems and less from the more socially immobile postcommunist systems in its educational social mobility than traditionally assumed in the research literature (e.g., Domański 2000; Mach 2004; Baranowska 2011). Consequently, from a European comparative perspective, there is a much greater need for further fair and increased access to higher education than what is commonly understood.

\section{The Demographic Decline and the Universal Fees Option}

Reducing inequality in access to higher education in Poland in the next decade depends on a number of factors: gross enrollment rates, wage premiums for higher education, the number of tuition-free vacancies and feebased vacancies available in the public sector, national higher education funding policies (including cost-sharing mechanisms in the public sector, state subsidization of the private sector, public investments in education and research infrastructure), the internationalization of studies, and enrollments of students outside of the traditional age range (Levine 1990; Holsinger and Jacob 2008; Knight 2009). Some factors may redefine public/private dynamics in the system without actually changing the current trend of inequality reduction. That is, the system may move gradually from a "dual and distinctive" ideal typical model to a "dual and homogenized" one, to use Levy's typology of public/private mixes in funding regimes: in this case, both sectors may be funded in the next decade in a similar manner, through fees and direct public subsidies (see Levy 1986). In this respect, further inequality reduction may thus be sector blind. In this article, the focus is more on the intersectoral public/private differentiation rather than on intrasectoral differentiation in any of the two sectors. ${ }^{6}$

Demographic shifts are expected to powerfully affect new admission patterns in both sectors and may increase access of lower socioeconomic classes to higher education throughout the system. For instance, the number of 19year-olds increased during the 1990s and until 2002. Since then, that number has been decreasing, and according to national demographic projections, it will continue to decrease for more than a decade. In 2020, there will be

\footnotetext{
${ }^{6}$ On the different kinds of differentiation in higher education, see Geiger (1986), Rhoades (1990), and van Vught (2009); on how social change in general can be seen as a process of differentiation, see Alexander and Colomy (1990).
} 
about 360,000 19-year-old Polish residents, compared with about 612,000 in 2005 and 534,000 in 2010 (GUS 2009). Also, the pool of potential students (traditionally in the 19-24 age bracket in Poland) will steadily decrease until at least 2020, from about 3.4 million in 2010 to about 2.3 million in 2020, in both urban and rural areas (that is a decrease of 31 percent within a decade). The decrease in the size of the population in the 19-24 age bracket will continue until 2025, and in 2035 that population will make up only about 64 percent of the 2007 population in that age range (GUS 2009).

Future trends regarding equitable access to higher education, inequality reduction, and admission patterns are linked to demographic forecasts, although one should remember that "the accuracy of population forecasts can only be assessed after the fact" (Preston et al. 2001, 135). In this particular case, simple population forecasts are likely to be fairly accurate because, for the period up to 2025, "the people have already been born and almost all of them will survive" (Frances 1989, 143); this assumes that there is no dramatic increase in the number of international students (currently below 1 percent of the student body) or in migration to Poland (currently marginal).

Just as there were several parallel routes by which educational expansion occurred in Poland (as shown above), there are several possible parallel routes leading to educational contraction. Overall, an increase in rates of access or a change in the length of studies may offset decreases in the cohort size. The length of study may change, and access rates depend on the eligibility rate and the proportion of those eligible who will actually enroll (which in turn depends on aspirations, incentives, but also numbers of vacancies): "the actual proportion of entrants also depends, among other things, on the cost of higher education, the financial pressures confronting those otherwise eligible, pecuniary (and non-pecuniary) advantages that they hope to gain from higher education and the length of their studies from an opportunity cost perspective" (Vincent-Lancrin 2008, 44). Additionally, student enrollment levels lag behind changes in the size of younger age cohorts, and demographic shifts take several years to be noticeable.

The fall in enrollment levels in Poland is projected to be one of the highest in Europe and comparable only to that occurring in other postcommunist countries: Bulgaria, Romania, Slovakia, Estonia, Lithuania, and Latvia. According to several enrollment scenarios based on national statistical data (e.g., Vincent-Lancrin 2008; Ernst \& Young 2010; IBE 2011; Instytut Sokratesa 2011), enrollments in Poland in 2025 are expected to have fallen to between 55 and 65 percent of the 2005 levels. In Western Europe, only Spain and Germany can expect decreases of more than 200,000 students by 2025 (Vincent-Lancrin 2008). Certainly, as Richard A. Easterlin $(1989,138)$ confirmed in the US context, there is an "inverse association between college enrollment rates and the size of the college-age population." Citing Carol Frances (1989, 143), Easterlin also mentions the cohort effect: "enrollment rates, in fact, 
partly depend on the size of the college-age population-other things remaining constant, at the aggregate level a larger college-age population makes for lower enrollment rates, while a smaller college-age population makes for higher rates" (Easterlin 1989, 137). Thus, demographic factors need to be combined with social, economic, and policy-related ones in any meaningful projections for the future.

Higher education systems in the OECD area in general are expected to continue to expand; as Paul Attewell put it in his global study of educational inequality around the world, "so far, the growth in demand for more years of education seems to have no limit. ... Each new generation exceeds its parents in terms of average years of schooling completed" $(2010,3)$. Therefore, implications of educational contraction for equitable access, institutional selectivity, and admissions criteria in Polish higher education (as well as higher education in postcommunist European countries such as Bulgaria, Romania, Estonia, Lithuania, Latvia, and Slovakia) remain important research areas. The institutional will to survive the demographic decline is overwhelming, but the logics governing access to publicly funded vacancies in the past expansion era may differ from those at work in the expected contraction era.

Access to higher education in Poland has been intertwined with public/ private dynamics (Duczmal and Jongbloed 2007; Kwiek 2008, 2011, 2012b). The biggest private higher education system in Europe ("independent private" in OECD statistical terms, fee based in practical terms) may be heavily dependent for its future survival on a change in higher education financingnamely, the introduction of universal fees (for both full-time and part-time students) in the public sector. If universal fees are not introduced, the size of the private sector may well undergo a steep decline in the next decade. Maintaining the tax-supported public sector under declining demographics might threaten the very existence of the private sector, given the following divergent trends: the decrease in the total number of students, the increase in the number of tuition-free vacancies in the public sector, and substantial public investments in public university infrastructure over the last 5 years. Arguably, mergers between public and private institutions are one of the potential survival strategies for the sector, as mentioned in the new law on higher education of March 18, 2011.

The decline of private higher education-according to the ministry's projections, its size is expected to decrease from 580,000 students in 2010 to 151,000 students in 2022 , that is, by almost 75 percent-is rarely addressed in the scholarly literature, as it is a rare phenomenon from a global perspective. The Polish case (along with a few other postcommunist European countries) is nearly exceptional in this respect, as both private shares in enrollments and absolute enrollments in the private sector have decreased between 2007 and 2011 and will decrease further. The private higher education sector may expect to have fewer students every year, a huge challenge 
for a system including 325 institutions. This may even be an existential one, as lamented by Polish conferences of private sector rectors (Konferencja Rektorów Uczelni Niepanstwowych and, since 2005, Konferencja Rektorów Zawodowych Szkól Polskich). As a recent study by the national Institute for Educational Research points out, "it has to be assumed that some of the newly created private institutions, [those with a] relatively poor educational offer, [which] opened to meet the demand from the generation from the $1980 \mathrm{~s}$ ... will not be able to survive" (IBE 2011, 110). These findings are consistent with Levy's global conclusions about private higher education $(2011,5)$ : "Much PHE [private higher education] has not had to offer very much, other than access and the prospect or hope of a degree. Logically, then, it is the demand-absorbing subsector of PHE that is most vulnerable when demands slows."

At the end of the day, however, given the low upward social mobility based on higher education, ensuring "fair" access to the latter and reducing social inequality in this respect is actually sector blind. From the perspective of equitable access, the intersectoral difference (i.e., future sector-related differentiation or de-differentiation) seem largely irrelevant. In a context of declining demographics, the expansion of a tuition-free public sector (from 0.85 million in 2010 to about 1 million students in 2020), along with the contraction of the fee-based private sector and of the system as a whole, may well contribute to widening access to higher education. From a sector-blind perspective, regardless of the future of the private sector institutions, under severe financial constraints the expansion of tuition-free vacancies in the public sector may contribute more to social justice (see Furlong and Cartmel 2009) than the emergence of fee-based vacancies in both sectors, with mechanisms of cost-sharing introduced universally across the two sectors.

\section{Conclusion}

Dramatically changing demographics in Poland set up new dilemmas related to public funding and admissions criteria in both public and private sectors. Public policy for higher education under contraction can be expected to be fundamentally different from public policy under expansion. This article has explored the question of inequality in access to higher education with reference to the past 2 decades of expansion and to the expected oncoming 2 decades of contraction. This contraction is at odds with a knowledge-economy policy discourse that generally ignores the prospect of sharply falling population levels. Educational contraction in a highly diversified and strongly market-oriented system may continue the trend of inequality reduction if national policies adequately respond to changing demographics combined with new social and economic determinants. There are several countries in the EU-all postcommunist new member states-in which similar demographic shifts lead to shrinking student populations to a comparable 
degree. Among those, Poland has the biggest higher education system and provides an inspiring case study, which is relevant for all countries in which changing public/private dynamics combine with falling birth rates. Powerful demographic shifts may change the structure of the system and allow for its remonopolization by the public sector. Therefore, a gradual decline of the private sector cannot be ruled out, even though market-driven private sectors have also been highly resilient and adaptable to changing environments. Ultimately, the intersectoral public/private differentiation of the expansion era may well be replaced by an intersectoral public/private de-differentiation (or homogenization) and a gradual decline of the private sector.

\section{References}

Alexander, Jeffrey C., and Paul Colomy, eds. 1990. Differentiation Theory and Social Change: Comparative and Historical Perspectives. New York: Columbia University Press.

Altbach, Philip G., Liz Reisberg, and Laura E. Rumbley. 2010. Trends in Global Higher Education: Tracking an Academic Revolution. Rotterdam: Sense.

Archer, Louise, Merryn Hutchings, and Alistair Ross. 2003. Higher Education and Social Class: Issues of Exclusion and Inclusion. London: Routledge.

Arum, Richard, Adam Gamoran, and Yossi Shavit. 2007. "More Inclusion than Diversion, and Market Structure in Higher Education." In Stratification in Higher Education: A Comparative Study, ed. Yossi Shavit, Richard Arum, and Adam Gamoran. Stanford, CA: Stanford University Press.

Attewell, Paul. 2010. "Education and Inequality in a Global Context." In Growing Gaps: Educational Inequality around the World, ed. Paul Attewell and Katherine S. Newman. Oxford: Oxford University Press.

Attewell, Paul, and Katherine S. Newman, eds. 2010. Growing Gaps: Educational Inequality around the World. Oxford: Oxford University Press.

Baranowska, Anna. 2011. "Does Horizontal Differentiation Make Any Difference? Heterogeneity of Educational Degrees and Labor Market Entry in Poland." In Making the Transition: Education and Labor Market Entry in Central and Eastern Europe, ed. Irena Kogan, Clemens Noelke, and Michael Gebel. Stanford, CA: Stanford University Press.

Bialecki, Ireneusz, and Małgorzata Dąbrowa-Szefler. 2009. "Polish Higher Education in Transition: Between Policy Making and Autonomy." In Structuring Mass Higher Education: The Role of Elite Institutions, ed. D. Palfreyman and D. T. Tapper. London: Routledge.

Bowles, Samuel, Herbert Gintis, and Melissa Osborne Groves, eds. 2005. Unequal Chances: Family Background and Economic Success. Princeton, NJ: Princeton University Press.

Breen, Richard. 2004. "The Comparative Study of Social Mobility." In Social Mobility in Europe, ed. R. Breen. New York: Oxford University Press.

Causa, Orsetta, and Åsa Johansson 2009a. "Intergenerational Social Mobility." OECD Working Paper no. 707, Organization for Economic Cooperation and Development, Paris. 
Causa, Orsetta, and Ảsa Johansson. 2009b. "Intergenerational Social Mobility in European OECD countries." OECD Working Paper no. 709, Organization for Economic Cooperation and Development, Paris.

DeShano da Silva, Carol, James Philip Huguley, Zenub Kakli, and Radika Rao, eds. 2007. The Opportunity Gap: Achievement and Inequality in Education. Cambridge, MA: Harvard Education Review.

Dobbins, Michael. 2011. Higher Education Policies in Central and Eastern Europe: Convergence towards a Common Model? London: Macmillan.

Domański, Henryk. 2000. On the Verge of Convergence: Social Stratification in Eastern Europe. Budapest: Central European University Press.

Duczmal, Wojciech, and Ben Jongbloed. 2007. "Private Higher Education in Poland: A Case of Public-Private Dynamics." In Public-Private Dynamics in Higher Education: Expectations, Developments and Outcomes, ed. Jürgen Enders and Ben Jongbloed. Bielefeld: Transcript.

Easterlin, Richard A. 1989. "Demography Is Not Destiny in Higher Education." In Shaping Higher Education Future: Demographic Realities and Opportunities, 1990-2000, ed. Arthur Levine. San Francisco: Jossey-Bass.

EC (European Commission). 2009. Youth in Europe. Brussels: EC.

EC (European Commission). 2011. "Supporting Growth and Jobs-an Agenda for the Modernisation of Europe's Higher Education Systems." Report no. COM(2011) 567/ 2, EC, Brussels.

Enders, Jürgen, and Ben Jongbloed, eds. 2007. Public-Private Dynamics in Higher Education: Expectations, Developments and Outcomes. Bielefeld: Transcript.

Ernst \& Young. 2010. Strategia rozwoju szkolnictwa uyzszego w Polsce do 2020 roku. Warsaw: Ernst \& Young.

Frances, Carol. 1989. "Uses and Misuses of Demographic Projections: Lessons for the 1990s." In Shaping Higher Education Future: Demographic Realities and Opportunities, 1990-2000, ed. Arthur Levine. San Francisco: Jossey-Bass.

Furlong, Andy, and Fred Cartmel. 2009. Higher Education and Social Justice. Maidenhead: Open University Press.

Geiger, Roger L. 1986. Private Sectors in Higher Education: Structure, Function, and Change in Eight Countries. Ann Arbor: University of Michigan Press.

Goedegebuure, Leo, V. Lynn Meek, Osmo Kivinen, and Risto Rinne. 1996. "On Diversity, Differentiation and Convergence." In The Mockers and Mocked: Comparative Perspectives on Differentiation, Convergence and Diversity in Higher Education, ed. V. Lynn Meek, Leo Goedegebuure, Osmo Kivinen, and Risto Rinne. New York: Pergamon.

GUS (Glówny Urzad Statystyczny). 1996. Higher Education Institutions and Their Finances in 1995. Warsaw: GUS [Central Statistical Office].

GUS (Glówny Urzad Statystyczny). 2009. Population Projection for Poland, 2008-2035. Warsaw: GUS [Central Statistical Office].

GUS (Glówny Urzad Statystyczny). 2011. Higher Education Institutions and Their Finances in 2010. Warsaw: GUS [Central Statistical Office].

Holsinger, Donald B., and W. James Jacob, eds. 2008. Inequality in Education: Comparative and International Perspectives. Hong Kong: Comparative Education Research Centre.

Huisman, Jeroen, and Frans van Vught. 2009. "Diversity in European Higher Ed- 
ucation: Historical Trends and Current Policies." In Mapping the Higher Education Landscape: Towards a European Classification of Higher Education, ed. Frans van Vught. Dordrecht: Springer.

IBE (Instytut Badan Edukacyjnych). 2011. Spoleczenstwo w drodze do wiedzy: Raport o stanie edukacji 2010. Warsaw: IBE [Institute for Educational Research].

Instytut Sokratesa. 2011. Demokratyczne tsunami: Raport Instytutu Sokratesa na temat wphywu zmian demograficznych na szkolnictwo uyższe do 2020 roku. Warsaw: Instytut Sokratesa.

King, Roger. 2004. The University in the Global Age. New York: Macmillan.

Knight, Jane, ed. 2009. Financing Access and Equity in Higher Education. Rotterdam: Sense.

Kwiek, Marek. 2006. The University and the State: A Study into Global Transformations. Frankfurt: Lang.

Kwiek, Marek, 2008. "Accessibility and Equity, Market Forces and Entrepreneurship: Developments in Higher Education in Central and Eastern Europe." Higher Education Management and Policy 20 (March): 89-110.

Kwiek, Marek. 2009. "The Two Decades of Privatization in Polish Higher Education: Cost-Sharing, Equity and Access." In Financing Access and Equity in Higher Education, ed. Jane Knight. Rotterdam: Sense.

Kwiek, Marek. 2010. "Creeping Marketization: Where Polish Private and Public Higher Education Sectors Meet." In Higher Education and the Market, ed. R. Brown. New York: Routledge.

Kwiek, Marek. 2011. "Universities and Knowledge Production in Central Europe." In Universities in the Knowledge Economy: Higher Education Organisation and Global Change, ed. P. Temple. New York: Routledge.

Kwiek, Marek. 2012a. "Changing Higher Education Policies: From the Deinstitutionalization to the Reinstitutionalization of the Research Mission in Polish Universities." Science and Public Policy 39 (October): 641-54.

Kwiek, Marek. 2012b. "Public-Private Intersectoral Competition: Fees and Declining Demographics." Compare 42 (February): 153-57.

Kwiek, Marek. 2013. Knowledge Production in European Universities: States, Markets, and Academic Entrepreneurialism. Frankfurt: Lang.

Kwiek, Marek, and Andrzej Kurkiewicz, eds. 2012. The Modernisation of European Unitersities: Cross-National Academic Perspectives. Frankfurt: Lang.

Kwiek, Marek, and Peter Maassen, eds. 2012. National Higher Education Reforms in a European Context: Comparative Reflections on Poland and Norway. Frankfurt: Lang.

Le Grand, Julian, and Will Bartlett, eds. 1993. Quasi-markets and Social Policy. Basingstoke: Macmillan.

Levine, Arthur. 1990. Shaping Higher Education Future: Demographic Realities and Opportunities, 1990-2000. San Francisco: Jossey-Bass.

Levy, Daniel C. 1986. "'Private' and 'Public': Analysis amid Ambiguity in Higher Education." In Private Education: Studies in Choice and Public Policy, ed. Daniel C. Levy. Oxford: Oxford University Press.

Levy, Daniel C. 2009. "Growth and Typology." In A New Dynamic: Private Higher Education, ed. S. Bjarnason et al. Paris: UNESCO.

Levy, Daniel C. 2011. "Public Policy for Private Higher Education: A Global Analysis." Journal of Comparative Policy Analysis 13 (August): 383-96. 
Mach, Bogdan W. 2004. "Intergenerational Mobility in Poland, 1972-88-94." In Social Mobility in Europe, ed. R. Breen. New York: Oxford University Press.

Meek, V. Lynn, Leo Goedegebuure, Osmo Kivinen, and Risto Rinne. 1996a. "Conclusion." In The Mockers and Mocked: Comparative Perspectives on Differentiation, Convergence and Diversity in Higher Education, ed. V. Lynn Meek, Leo Goedegebuure, Osmo Kivinen, and Risto Rinne. New York: Pergamon.

Meek, V. Lynn, Leo Goedegebuure, Osmo Kivinen, and Risto Rinne, eds. 1996b. The Mockers and Mocked: Comparative Perspectives on Differentiation, Convergence and Diversity in Higher Education. New York: Pergamon.

Ministry of Science and Higher Education. 2012. "The Project on Assumptions of the Law on Changing the Law on Higher Education and Related Laws." [In Polish.] Photocopy, November 28.

OECD (Organization for Economic Cooperation and Development). 2008. Higher Education to 2030. Vol. 1 of Demography. Paris: OECD.

OECD (Organization for Economic Cooperation and Development). 2011. Education at a Glance, 2011: OECD Indicators. Paris: OECD.

Orr, Dominic, Christoph Gwosc, and Nicolai Netz. 2011. Social and Economic Conditions of Student Life in Europe. Bielefeld: Bertelsmann.

Pfeffer, Jeffrey, and Gerald R. Salancik. 1978. The External Control of Organizations: A Resource Dependence Perspective. Stanford, CA: Stanford University Press.

Preston, Samuel, Patrick Heuveline, and Michel Guillot. 2001. Demography: Measuring and Modeling Population Processes. Oxford: Blackwell.

Rhoades, Gary. 1990. "Political Competition and Differentiation in Higher Education." In Differentiation Theory and Social Change: Comparative and Historical Perspectives, ed. Jeffrey C. Alexander and Paul Colomy. New York: Columbia University Press.

Santiago, Paulo, Karine Tremblay, Ester Basri, and Elena Arnal. 2008. Tertiary Education for the Knowledge Society. Vol. 1 of Special Features: Governance, Funding, Quality. Paris: OECD.

Schomburg, Harald, and Ulrich Teichler, eds. 2011. Employability and Mobility of Bachelor Graduates in Europe: Key Results of the Bologna Process. Rotterdam: Sense.

Shavit, Yossi, Richard Arum, and Adam Gamoran, eds. 2007. Stratification in Higher Education: A Comparative Study. Stanford, CA: Stanford University Press.

Szczepański, Jan. 1974. Higher Education in Eastern Europe. New York: International Council for Educational Development.

Van Vught, Frans. 2009. "Diversity and Differentiation in Higher Education." In Mapping the Higher Education Landscape: Towards a European Classification of Higher Education, ed. Frans van Vught. Dordrecht: Springer.

Vincent-Lancrin, Stéphan. 2008. "What Is the Impact of Demography on Higher Education Systems? A Forward-Looking Approach for OECD Countries." In Higher Education to 2030. Vol. 1 of Demography. Paris: OECD. 


\section{Fair Access to}

\section{Higher Education Global Perspectives}

Edited by Anna Mountford-Zimdars,

Daniel Sabbagh, David Post 
The University of Chicago Press, Chicago 60637

The University of Chicago Press, Ltd., London

$\begin{array}{lllllllllll}18 & 17 & 16 & 15 & 14 & 5 & 4 & 3 & 2 & 1\end{array}$

(C) 2014 by The University of Chicago

All rights reserved. Published 2014

Printed in the United States of America

\section{Library of Congress Cataloging-in-Publication Data}

Fair access to educaton : global perspectives / edited by Daniel Sabbagh, David Post, and Anna Mountford-Zimdars.

pages $\mathrm{cm}$

ISBN 978-0-226-25092-2 (pbk. : alk. paper) - ISBN 0-226-25092-X (pbk. : alk paper) ISBN 978-0-226-26890-3 (ebook) 1. Universities and colleges-Admission-Social aspects. 2. Universities and colleges-Entrance requirements-Social aspects. 3. Education, Higher-Social aspects. 4. Educational equalization. I. Post, David, editor. II. Sabbagh, Daniel, editor. III. Mountford-Zimdars, Anna, 1979- editor

LB2351.F35 2014

378.1 '61-dc23 


\section{CONTENTS}

\section{Introduction}

DANIEL SABBAGH, ANNA MOUNTFORDZIMDARS, AND DAVID

1 Fair Access to Higher Education: A Comparative Perspective

POST

\section{Articles}

FRANK L. SAMSON

11 Altering Public University Admission Standards to Preserve White Group Position in the United States: Results from a Laboratory Experiment

STEVEN JONES

39 "Ensure That You Stand Out from the Crowd": A Corpus-Based Analysis of Personal Statements according to Applicants' School Type

MAIA CHANKSELIANI

JENS PETER THOMSEN, MARTIN D. MUNK, 66 Rural Disadvantage in Georgian Higher Education Admissions: A Mixed-Methods Study

98 The Educational Strategies of Danish University Students from Professional and Working-Class MISJA EIBERG-MADSEN, AND GRO INGE Backgrounds

HANSEN

YAËL BRINBAUM AND CHRISTINE GUÉGNARD

122 Choices and Enrollments in French Secondary and Higher Education: Repercussions for SecondGeneration Immigrants

PEPKA ALEXANDROVA 143 Admissions Policies as a Mechanism for Social BOYADJIEVA Engineering: The Case of the Bulgarian Communist Regime

ELIZABETH BUCKNER 167 Access to Higher Education in Egypt: Examining Trends by University Sector

MAREK KWIEK 193 From System Expansion to System Contraction: Access to Higher Education in Poland

THOMAS J. 216 Access and Affordability in American Higher ESPENSHADE AND Education MELANIE WRIGHT FOX

PETER STONE 248 Access to Higher Education by the Luck of the Draw 271 Contributors

273 Index 